\title{
EDITORIAL
}

\section{A POESIA NO LIMITE OU OS (DES)LIMITES DA POESIA}

is uma questão que nos faz hesitar entre a impossibilidade de lhe darmos resposta e a possibilidade de propormos várias respostas diferentes: "o que é um poema?". Antes de querermos responder a uma demanda que se ancora nos primórdios da linguagem humana, pensamos em paralelo que o poema, grosso modo, comporta-se como um "travesti" da linguagem. Ou seja, compõe-se de partes que, sendo aparentemente dissonantes entre si - ou mesmo discordantes -, conformam-se apenas no ato que se faz no todo performativo da linguagem, não tendo, portanto, limites aparentes que circunscrevam a sua capacidade de sempre tornar aquela mesma linguagem outra. Em mesma medida, se o poema atua no campo nebuloso criado em torno de sua materialidade própria, ele constantemente rearticula formas e formatos, num eterno convite à participação de expressões variadas que, não sendo na sua matriz "poéticas", rompem o seu próprio limite e passam a habitar, estar, "ocupar" essa nova casa.

O que ao longo dos tempos mereceu esta designação, "poema", é algo tão diverso e instável, tão heterogêneo em termos de meios e propósitos, que fazer a pergunta "o que é um poema?" não pode deixar de criar um certo embaraço; tentar responder-lhe talvez crie um embaraço maior ainda. Daí que as respostas comecem muitas vezes por uma restrição e procurem limitar-se a formulações como estas: o que é um verdadeiro poema, ou o que é a grande poesia, ou o que é um poema moderno, ou que é a poesia barroca, românti$c a$, a poesia política, etc. Ou então a busca de uma resposta para esse tipo de questões pode começar por outro tipo de delimitação, mediante um critério de avaliação assumidamente pessoal.

Talvez devamos começar por pôr em causa a própria possibilidade de definirmos conceitualmente algo que possa ser singularizado por um artigo definido como $a$ poesia, ou como o poema. Essa reserva é suscitada pela constatação da falibilidade de certos pares pretensamente essencialistas e falsamente opo- 
sitivos, como poesia/prosa, poesia/ficção etc. Jean-Luc Nancy colocou a questão de um modo simples, embora sem iludir a sua complexidade, quando restringiu drasticamente o âmbito da palavra "poesia": "Poesia não tem exatamente um sentido, mas antes o sentido do acesso a um sentido a cada momento ausente, e transferido para longe. $O$ 'sentido' de poesia é um sentido sempre por fazer", escreveu o filósofo em Resistência da poesia. Independentemente de contextos e especificidades genológicas, talvez o sentido primeiro da palavra esteja precisamente na designação da possibilidade de criarmos "uma língua dentro da própria língua" (Herberto Helder dixit), em concordância com princípios apenas inferíveis de uma multiplicidade concreta de práticas de experimentação discursiva, princípios que, por isso mesmo, sempre serão infixos, susceptíveis de reformulação e inquirição. Nessa medida, a expressão que dá título a este número da Revista Via Atlântica, "a poesia no limite", pode ser entendida como uma espécie de equação tautológica, um sublinhado: a poesia ou acontece no limite ou não acontece de todo. E entenda-se como "limite" o que dela nos é dado conhecer e descrever de modo explícito e sistemático. Se, como diz Nancy, "o 'sentido' de poesia é sempre um sentido por fazer", toda a descrição fazível de "poesia" induz a necessidade de a poesia ser outra poesia, ou seja, promove a distensão desse limite. Há um excesso que a língua e o mundo nos facultam sem todavia nos mostrarem como falar dele. Talvez as tentativas de o dizer se chamem "poesia".

Por outro lado, e tendo garantida sua comunicabilidade com o mundo, o poema também se traduz na recomposição da realidade, apenas que agora numa clave que amalgama ficção, autoficção, aforismo, relato, testemunho ou falseamentos que não são, senão, processos e procedimentos que constantemente o redimensionam, reconfigurando seus limites e a sua atuação como realização particular da linguagem.

Compreendendo essa multiplicidade, tanto da forma quanto do conteúdo, somada ainda a dinâmica de colaboração mútua, constante e plurívoca que mantém essas duas instâncias, o número 32 da Revista Via Atlântica contempla artigos e ensaios de pesquisadoras e pesquisadores atentos às dinâmicas do poema, seja nas suas expressões mais tradicionais - como no caso da revisão de aspetos da lírica horaciana -, seja passando por reflexões sobre alteridade, autoria e ficcionalização poéticas, e chegando às formas de homologia e analogia entre as corporeidades e seus procedimentos representacionais no poema. 
Trata-se, pois, de um número que se dedica às múltiplas formas de abordarmos a palavra poética, considerados os seus (des)limites no universo cultural contemporâneo ou mesmo alguma tentativa de resgate de alguns procedimentos essenciais do poema dentro do quadro maior das literaturas africanas, americanas, europeias ou do Índico.

No mais, "os versos que te digam..." (Carlos de Oliveira, "Bolor").

Annie Gisele Fernandes (Universidade de São Paulo)

Rosa Maria Martelo (Universidade do Porto)

Emerson Inácio (Universidade de São Paulo) 